\title{
fabulate ergo sum: a criação, o currículo e o cuidado com a vida
}

\author{
steferson zanoni roseiro \\ rede municipal de ensino de cariacica/es \\ universidade federal do espírito santo, espírito santo, brasil \\ orcid id: https:/ / orcid.org/0000-0003-1424-2281
}

resumo

Este artigo discute a possibilidade de fazer da fabulação um método de pesquisa coletivo, apresentando o conceito de fabulação criado por Henri Bergson e ampliado por Gilles Deleuze e Félix Guattari para, no limite, fazer nascer o método. Partindo do princípio de que as forças vitais são minadas pela máquina capitalística, o texto indaga as possibilidades de insurreição e de apego à vida nas escolas. Se a fabulação tem um lado obscuro inclinado para a regulação da vida, a filosofia da diferença dá ao conceito a possibilidade de ampliação dos compossíveis da imanência. Fabular seria, então, uma questão de criar possíveis para a existência. Assim, este texto propõe fabular, com alunos de uma escola periférica no município de Cariacica-ES, condições de produção coletiva de vida a partir da própria escola. Desse modo, diante do imperativo funcional e mercantil que rege a escola e as produções curriculares, aborda algumas das questões e dificuldades encontradas no processo de fabulação como método. Por fim, aponta a fabulação como criação de um comum que afete os corpos. Eis, então, uma fabulação que destitui o lugar de autoria para criar um corpo coletivo capaz de criar vazios que expandam os limites da vida.

palavras-chave: fabulação; currículo; comum; método de pesquisa; escola.

\section{fabulate ergo sum: creation, curriculum and care for life}

abstract

This essay discusses the possibility of turning what Henri Bergson, Gilles Deleuze and Felix Guattari called "fabulating" into a collective research method, insomuch as Deleuze and Guattari identified it as the invention of a collectivity that does not yet exist, a people to come. Given our current situation, in which the vital force of contemporary collectivities is undermined by the capitalist machine, this text inquires into the possibilities of an insurrection that begins with life in schools. If, as Bergson claimed, fabulating has a dark side that is inclined to the regulation of life, a philosophy of difference, on the other hand, conceptualizes the possibilities inherent in lived immanence. To fabulate would be, then, a question of creating possible existences. As such, this text proposes to fabulate, together with students from a suburban school in the municipality of Cariacica-ES, possible conditions of collective life in the school itself. Faced as it is by the market imperatives that govern the school and its curriculum, fabulation offers an approach and a methodology that promises to overcome this negative educational climate by fashioning larger than life images that transform and metamorphose conventional representations and concepts of collectivities, thereby enabling the invention of a people to come, and the creation of a commons and of a collective body capable of creating cognitive and affective domains that expand the limits of life.

keywords: fabulation; curriculum; common; research method; school. 


\section{fabulate ergo sum: la creación, el currículum y el cuidado con la vida}

resumen

Este artículo discute la posibilidad de hacer de la fabulación un método de investigación colectivo, presentando el concepto de fabulación creado por Henri Bergson y ampliado por Gilles Deleuze y Félix Guattari para, en el límite, hacer nacer el método. Partiendo del principio de que las fuerzas vitales son minadas por la máquina capitalista, el texto indaga las posibilidades de insurrección y de apego a la vida en las escuelas. Si la fabulación tiene un lado oscuro inclinado a la regulación de la vida, la filosofía de la diferencia da al concepto la posibilidad de ampliación de los composibles de la inmanencia. Fabular sería, entonces, una cuestión de crear posibles para la existencia. Así, este texto propone fabular, con alumnos de una escuela periférica en el municipio de Cariacica-ES, condiciones de producción colectiva de vida a partir de la propia escuela. De ese modo, ante el imperativo funcional y mercantil que rige la escuela y las producciones curriculares, aborda algunas de las cuestiones y dificultades encontradas en el proceso de fabulación como método. Por fin, apunta la fabulación como creación de un común que afecte a los cuerpos. He aquí, pues, una fabulación que destituye el lugar de autoría para crear un cuerpo colectivo capaz de crear vacíos que expandan los límites de la vida.

palabras clave: fabulación; currículum; común; método de investigación escuela. 
fabulate ergo sum: a criação, o currículo e o cuidado com a vida

\section{as distopias do agora}

Não nos faltam distopias no tempo presente. O cenário pós-apocalíptico tão alimentado nos cenários gráficos de jogos digitais, na literatura e no cinema pop mundial não consegue dar conta da realidade que nos assombra e, todavia, não retarda seus movimentos.

As distopias não são apenas da ordem da ficção nem sequer se apresentam tão descaradamente para todos. Talvez, tal qual no cenário de Admirável Mundo Novo ou em Fahrenheit 451, devamos dizer que existe uma parcela da população que nem sequer sinta as distopias do presente. Existe uma horda de corpos diante de telas (Comitê Invisível, 2017), amarrados e capturados pelas produções maquínicas anestesiantes, e a eles as distopias parecem ainda ficções científicas ou equidistantes a povos estranhos e estrangeiros do outro lado do universo, do planeta, ou, no mínimo, da cidade.

Há uma geração PlayStation (Pelbart, 2019) acostumando-se diariamente às chacinas produzidas por joysticks e ataques bem coordenados. Uma geração que, diante das telas, se sente desconectada dos mundos precários (Butler, 2015) que se multiplicam para todos os lados. Há uma geração tão acostumada às telas e aos distanciamentos que, quando adentramos o cenário pandêmico em $2020^{1}$, parece nem sequer ter percebido uma série de mudanças nas subjetividades em produção. Há uma geração que, de algum modo, se acostumou a tal ponto com a violência e a apatia, que, não raro, discute a quantidade de sangue que deveria ser jorrada em um ou outro programa televisivo, em uma ou outra situação.

O cenário político, ético e estético, em que nos encontramos no início do terceiro decênio do século XXI, evoca, para todos os lados, um conjunto de ataques fascistas desferidos contra infinitas populações. Se antes Foucault (2014) anunciava, ao prefaciar o livro $O$ Anti-Édipo, que o fascismo era um dos três adversários que ameaçavam a expansão da vida, é, decerto, preciso enfatizar que, na conjuntura

\footnotetext{
${ }^{1}$ Em março de 2020, a Organização Mundial da Saúde decretou estado de pandemia da nova variação do coronavírus, o Sars-Cov-2.
} 
atual, que o fascismo já se aliou aos outros dois inimigos declarados à época pelo filósofo: os ascetas políticos e os técnicos do desejo. Hoje, como pondera Safatle (Cult, 2018), não há fascismo sem a ressurreição de uma noção de unidade. Tudo o que deturparia tal imagem seria, deveras, inimigo a ser reduzido ao nada.

Não ao acaso, mencionamos as distopias.

Os enquadramentos teorizados por Suzan Sontag, e discutidos, com base em Judith Butler (2015), dos corpos passíveis de abandono têm evidenciado que algumas parcelas da população estão no princípio das práticas de governamento. A precariedade que marca esses corpos concede a eles um caráter de laboratório de experimentações. Se o fascismo evoca uma política de unidade, a precariedade enquadra um padrão de vida, e tudo o que está fora dos limites desse quadro é passível de guerra, de morte, de extermínio. Fora do enquadramento, corpos deixam de ser enlutáveis.

Seríamos, então, os restos de uma unidade, os borrões de um enquadramento.

Os governos anunciam milhões de estratégias contra nós, valendo-se sempre do cenário apocalíptico que ameaça as forças coletivas. O argumento é o mesmo usado por Margaret Thatcher: there is no alternative (não há alternativas): a reforma da previdência social aprovada em 2019, no Brasil; os cortes ("contingenciamentos") feitos às instituições federais de educação; a retirada da incorporação de aumento salarial de funcionários federais; a privatização de boa parte de ações e partes das empresas estatais; o limite percentual de bolsas de pesquisa disponíveis a cada programa de pós-graduação; os acordos milionários feitos entre a rede pública de ensino e o setor privado. Tudo sob a aldrava de que não há alternativas. Anunciam os cavaleiros do apocalipse quando, claramente, eles já estão aqui.

As distopias são um investimento político bem coordenado.

As práticas de governamento dos corpos nesse jogo de multiplicação de fascismos e de intensificação das distopias parecem produzir em nós um medo inexplicável do outro. Esquecemos de efetivamente viver, nos encontrar uns com os outros e nos dar às reais possibilidades de criação de vida advindas desses encontros.

Quando não há mais experiência comum, salvo encontrar-se diante das telas, é possível criar breves momentos de comunhão nacional 
depois dos atentados, despertando todo sentimentalismo meloso, falso e oco; é possível decretar todos os tipos de 'guerras contra o terrorismo' [ou 'guerras contra o tráfico'], prometer recuperar todas as 'zonas de não direito' que se queira, mas isso não passa de um boletim de notícias da BFM-TV no fundo de uma lanchonete, e, portanto, não ouvimos seu som (Comitê Invisível, 2017, p. 33).

É preciso retomar a criação do comum como princípio necessário à existência. Conforme sugeriu o Comitê Invisível (2016), é necessário habitar plenamente a vida como um modo de enfrentar as políticas de merda que lançam sobre nós.

Fugindo à regra de que não há alternativas, pensando no propósito de habitar plenamente a vida e enfrentando as distopias que esfacelam o presente e o futuro, ponderamos sobre o próprio lugar da pesquisa científica nas ciências humanas e, em nosso caso particular, na educação. É possível fazer pesquisa de modo a produzir comuns entre os corpos? É possível praticar um modo de pesquisar e, ao mesmo tempo, ampliar os possíveis ao invés dos apocalipses?

Evidentemente essa é uma recorrência em todo o desenrolar da história das ciências humanas. Em cada circunspecto das epistemologias, é possível encontrar rupturas entre os modos de produção de realidades advindas de métodos (Santos, 2007): questionários, entrevistas, ações participantes, imersões em campo, observações. Em cada perspectiva, inclusive, é possível encontrar milhões de justificativas para o uso de seus métodos e a rejeição de outros.

E se a produção de real (encontro do atual com as virtualidades) na pesquisa fosse, a um só tempo, a produção de seu real ficcionado, fabulado? E se a produção de realidades compossíveis com os tempos de enfrentamento fosse a própria objetividade do método de pesquisa? Isto é, e se o real-atual intercambiasse com os reais-possíveis/desejáveis de modo a produzir imagens do real a partir dessas virtualidades?

Ao pensarmos um pouco nessas questões, colocamo-nos, em 2018, em pesquisa com alunos do $6^{\circ}$ e $7^{\circ}$ anos de uma escola periférica do município de Cariacica-ES, propondo pensar a fabulação como um método coletivo de pesquisa tanto quanto um modo de escrita acadêmica. Pesquisávamos, portanto, as possibilidades insurrecionais emergentes na fabulação. E, estando em escolas e falando de pesquisas em educação, não tínhamos outra intenção senão a de fabular a própria escola. E, todavia, ainda indagávamos se era possível produzir algo em 
uma pesquisa científica que fosse mais da ordem das mudanças afetivas para com o mundo e, em especial, a escola. É possível criar em uma pesquisa acadêmica? Mais: é possível que a criação não seja do pesquisador, mas, de algum modo, seja de todos envolvidos na pesquisa? E, nessa criação, é possível que o mundo criado provoque em nós um maior interesse por esse espaço que chamamos de escola?

Assim, apresentamos, neste artigo, o movimento de fabulação como um método coletivo de criação do comum. Aqui o fabular não é da ordem de um indivíduo, de um ser de superioridade artística ou filosófica. Fabular, para nosso intento, é uma questão de produção entre corpos. Como criar vidas que desloquem os sentidos imediatos e expandam o real para além dos limites conhecidos? Assim, apresentamos, nesse texto, não as próprias fábulas criadas, mas o movimento de fabular. Para tanto, recorremos a recortes de conversas tecidas com os alunos envolvidos no processo de fabulação ${ }^{2}$ e alguns dos desafios encontrados para tal.

Se se decompõe o presente com promessas apocalípticas, é preciso que enfrentemos o presente criando futuros cabíveis, futuros vivíveis. Henri Bergson (2005) deixou claro que os governos aprenderam, há muito, a arte de fabular como um modo de controlar os medos e as ansiedades dos corpos, fazendo-os acreditar nas devastações, nos infernos. Os corpos são governados justamente quando lhes adormecem as forças insurrecionais (Comitê Invisível, 2016). Todavia, a um só tempo, Bergson alude que a fabulação tem outra possibilidade, essa muito mais vitalista: a de criar futuros possíveis de modo que aumente nosso grau de apego à vida.

Se viver hoje adoece, fabulemos, pois, os tempos férteis em vida.

\section{função afetiva da fabulação}

Tão logo o humano aprendeu a usar a linguagem, fizemos o uso de nossas capacidades fabuladoras. Criamos seres, histórias, deuses e acasos em que as coisas pudessem ter certo sentido. Tudo precisava de uma história, um acontecimento,

\footnotetext{
${ }^{2}$ As falas e conversas aparecerão ao longo do texto entre aspas e em itálico e, por vezes, separadas do próprio texto com entrelinhas simples e em itálico. As falas e conversas seguem o propósito de uma rede de conversas em que não importa quem diz o quê, mas que as coisas sejam ditas e ganhem vida por serem enunciadas. Assim, não há nenhum modo de identificação nas falas, implicando, assim, diferentes modos de ler quem as enuncia.
} 
uma vida. Desde as mais simples das criações - o espírito de uma árvore, talvez até os mais complexos dos seres - as divindades, quiçá -, ambos tomaram a função fabuladora ${ }^{3}$ como o princípio de sua existência e sua condição de existência.

Há, decerto, toda uma capacidade criadora que atravessa a nossa história. E, a todo o momento, ela é atrelada ao papel de regulação da vida, de manter a ordem e o sentido das coisas. Bergson (2005) deixou bem claro que, embora o humano seja um animal dotado de uma inteligência diferente das demais, a natureza cobrou dele um alto preço por sua inteligência: a ciência de sua finidade, a percepção do adoecimento e do esvaziamento da vida. O humano seria, para ele, o único animal ciente de sua morte inadiável. E, diante de tal cenário, perguntar-se-ia o sentido da vida.

Daí surgiria, justamente, a função fabuladora como alternativa à morte, assegurando a sociedade e a vida individual de cada ser.

O homem não pode exercer a sua faculdade de pensar sem se representar um futuro incerto, que desperta o seu medo e a sua esperança. [...] De facto, a função efabuladora, que pertence à inteligência mas não é apesar disso inteligência pura, tem precisamente esse fim. [...] É uma reação defensiva da natureza contra o que poderia haver de deprimente para o indivíduo, e de dissolvente para a sociedade, no exercício da inteligência (Bergson, 2005, p. 174-175).

A função fabuladora traria, assim, a própria condição de existência do humano enquanto tal. Se a inteligência ímpar seria o que lhe permitiria diferenciarse de outros seres vivos - diferenciar-se, inclusive, por não aceitar a própria condição -, a fabulação seria a cola que mantém unida as pessoas e as coisas por criarem coletivamente histórias que pusessem os humanos em relação.

Em miúdos, a função fabuladora cumpriu o papel da religião e a fez nascer quando a sociedade humana se estendeu para além dos limites das comunidades. A partir dela, fez-se a religião para que os povos pudessem viver conforme regras e valores, para que pudessem dar um sentido à vida e às relações que estabeleciam. Conforme sugere Gabriel Cunha (2014, p. 91-92), o conceito da função fabuladora tinha tudo que ver com o passado, com o virtual e com a estruturação do presente.

\footnotetext{
${ }^{3}$ Na versão portuguesa do livro As duas fontes da moral e da religião, o termo aparece como função efabuladora; portanto, cumpre destacar que se trata, em absoluto, da mesma função. Porém, advindo de uma leitura da filosofia da diferença com base em Gilles Deleuze e Félix Guattari, o termo popularizou-se no Brasil como fabulação ou função fabuladora.
} 
"Bergson via na faculdade fabuladora a mediação ou a transformação da experiência desarrazoada em cálculo político" capaz de estabilizar as virtualidades, sendo, ainda, "responsável por produzir um conjunto de ficções que trazem estabilidade para uma ordem social e identitária fechada a partir da difusão de uma moralidade exemplar". Ou seja, a função fabuladora criava entre os seres uma ordem naturalizada que implicaria certa harmonia ou, pelo menos, imporia certo modo de viver. Quão mais fortes fossem as fábulas criadas, quão mais trabalhadas elas fossem, mais envolveriam as pessoas em suas ações, suas estratégias - maior seria, portanto, o poder da moral nessa relação.

Teríamos, sob essa perspectiva, a fabulação como a criação dos sentidos e das regras de convivência social, regras que não apenas aceitamos, mas também as consideramos naturais à vida.

A função fabuladora teria, assim, uma função política de controle criada sob aparente neutralidade ou razoabilidade.

Em sua explícita relação entre a religião e com a criação de regras, com a manutenção do social e a retroalimentação das dependências espirituais do humano, a fabulação, "quando portadora de eficácia, é como uma alucinação nascente: é capaz de contrabalancear o juízo e o raciocínio" (Bergson, 2005, p. 100). A fabulação faria, assim, circularem as ideias e os afetos. Talvez pudéssemos dizer que há, na explicação por meio das fábulas, certa função de regulação e vamos encontrá-la em pleno exercício, seja nas deusas criadas para aumentar ou garantir a fertilidade na antiguidade, seja na aceitação quase unânime de que as mães adolescentes não podem dar a "estrutura" necessária ao aprendizado de uma criança. Em ambos os casos, vemos os aparatos fabuladores funcionarem a fim de criar, entre os corpos, certos padrões de comportamento, modos de pensar e agir. A criação das deusas férteis de um lado e a das bobas mães adolescentes de outro. Os personagens incitam exatamente o que suas histórias lhes exigem.

Todavia, essa não seria sua única possibilidade. Conforme Bergson (2005) e, mais tarde, Gilles Deleuze (2014) deixam bem claro, relacionamo-nos com os personagens fabulados. Ainda que a fabulação tenha uma função explicativa e reguladora, ela só existe quando é capaz de criar "personagens cujas histórias nós 
contamos" (Bergson, 2005, p. 167). E, quando nos relacionamos com uma história, ela consegue jamais se manter inalterada. Quão mais real uma fabulação se faz isto é, quão mais evocada, quão mais próxima da vida das pessoas ou quanto mais ela afeta os corpos em suas passagens -, mais ela será exercitada, mais passará por transformações, por indagações, por sentidos.

Uma vez jogado no mundo, um personagem fabulado ganha vida própria.

Certamente é possível que todos os professores do planeta conheçam alguma menina que foi mãe precoce e inadvertidamente essa menina-mãe não conseguiu lidar bem com a situação da maternidade. Infelizmente, logo nos esquecemos das adversidades culturais, sociais, psicológicas, econômicas e políticas envolvidas nisso e dizemos, se muito, que o "acaso" não foi generoso com essa mãe. A culpa, se não for completamente dela, será da sorte que não lhe sorriu. Não tarda para que essas histórias reforcem o caráter regulador da função fabuladora. Não é preciso sequer muito esforço. Ainda assim, a função fabuladora não cumpre apenas esse caráter regulador. Sendo posta a circular, ela também assume uma função afetiva. Nada nos impede de nos depararmos com os personagens das grandes funções fabuladoras e nos relacionarmos com eles de modos pouco esperados pelas práticas religiosas e de governo. Diante da figura fabulada da mãe adolescente, não há uma única opção possível (o medo) - pode haver também interesse, vontades. Uma menina pode descobrir-se ciente de todas as adversidades e, do mesmo modo, desejar a gravidez na adolescência; pode descobrir outros sentidos na vida; pode apegar-se à vida.

Se resta à função fabuladora apenas o caráter de regulação, poder-se-ia abandoná-la de imediato. A situação política em nosso país, hoje, é pura função fabuladora. Abraham Weintraub seria, decerto, exímio fabulador quando alegou que as universidades federais escondem plantio de maconha; Jair Messias Bolsonaro (vulgo presidente) teria demonstrado sua faculdade fabuladora com mestria, ao alegar, em pronunciamento nacional, que a nação já pode voltar às ruas e ao trabalho sem o menor dos riscos, porque a Covid-19 seria apenas uma "gripezinha" para a maioria da população. Mas o que poderíamos esperar de um 
presidente que foi eleito ao criar como personagem fabulado a mamadeira de piroca para ganhar a eleição?

Não muito, certamente.

A partir da experiência afetiva com a função fabuladora, os personagens fabulados são colocados em contato com os corpos e ali eles geram efeitos imprevisíveis no modo como vivemos. Não apenas as divindades guiam os modos como agimos e nos posicionamos no mundo - infinitos outros personagens são diariamente evocados em conversas tanto para regular quanto para nos lembrar da possibilidade de diferenciação infinita. Relacionamo-nos tanto com figuras reais quanto com fictícias. Sherlock Holmes foi a tal ponto posto em exercício de fabulação que ocasionalmente é impraticável que ele não tenha existido efetivamente - em cada buraco, em cada esquina, esse personagem é evocado como parâmetro de grandeza, como incentivo às descobertas ou mesmo por meio da sátira e do deboche. Entre crianças, ativamente figuram fadas, sereias, princesas e guerreiros no plano do imaginário, atravessando o presente em direção aos futuros almejados pelos pequenos.

Quando deixa de ser a função fabuladora, a criação não passa a ser apenas de personagens, mas de planos de composição e vazios (Deleuze; Guattari, 2010). Aqui nossas faculdades de nos envolvermos nos universos fabulados ativam afetos não humanos, devires apocalípticos e enfrentam o real imediato, abrem os atuais do tempo a virtualidades. Ao analisar o trabalho cinematográfico de Pierre Perrault, Deleuze (2013) contrapõe a ficção à fabulação, alegando que a primeira mantém, ainda, um desejo doentio para com a verdade, enquanto a fabulação, por sua vez, dá ao falso e ao inexistente uma potência de vida única. Fabular implica, em dada medida, desdevir o próprio mundo (Culp, 2020), destruí-lo radicalmente enquanto verdade, enquanto produção única, enquanto reino da produção capital. É preciso proclamar a morte do mundo para fazer nascerem outras forças, para fazerem eclodir - das superfícies - modos de vida incompossíveis com o atual (Deleuze, 2013).

A morte do mundo passaria, então, por um processo de romper com os conectores imediatos da vida que existem como alternativa única para, então, fazer 
nascerem os possíveis. Essa, justamente, seria a afirmação da potência do falso e da expansão dos vazios (Deleuze; Guattari, 2010). Se a fabulação transforma o jogo de verdade em um aparato questionável a partir de personagens e elementos carregados de uma força falsária, ela não o faz para afirmar uma nova verdade única e inquestionável. Fabulamos justamente para ampliar os possíveis no mundo (Marques, 2004), para evocar forças que estão para além do mundo tal qual o conhecemos.

Fabular implica criar vazios mesmo onde tudo parece demasiado povoado.

Na obra deleuziana inspirada nas pinturas de Francis Bacon (Deleuze, 2007), deparamo-nos com uma escrita que busca superar os clichês a partir de uma prática de esburacar as imagens preexistentes. Para Deleuze, antes do pintor fabular seu universo, esse pintor teria o trabalho de retirar da tela as imagens (os clichês) que antecipam o ato de pintar.

Seria então trabalho do corpo fabulador esvaziar o mundo dos clichês?

Criar vazios poderia ser lido como esse movimento de remover da tela - da escrita, da pesquisa, do encontro... - todos os clichês, esvaziá-lo de sentidos preexistentes. Todavia, nem de longe seria esse o ponto aqui defendido. Argumentava Deleuze (2007, p. 93) que "as reações contra os clichês engendram clichês". Isto é, a própria luta contra os clichês já criou imagens clichês. Restar-nosia, então, a necessidade de indagar pelas condições de nossas lutas. Como defrontar o clichê? Como escapar do clichê e das lutas contra ele?

Quando o autor se aproxima de uma resposta em sua leitura com o cinema, é para falar aquilo que sempre nos pareceu impróprio: fazendo o falso aparecer, invadindo o real com uma força falseante. $\mathrm{O}$ falso teria esse papel justamente de evocar uma potência quando tudo nele indica certa "semelhança". O falso não é a mentira ou o errado. Antes, a vida falseia quando mantém sob dados limites tudo como estava, como deveria ser para, por outras lógicas, romper os fluxos esperados (Deleuze, 2013).

O falso mantém certas lógicas reconhecíveis para eclodir monstruosidades.

Quando o falso ganha cena e expande as possibilidades de funcionamento e de fluidez da vida, ele evoca nada menos que as virtualidades. Aqui, a potência do 
falso faz as imagens clichês se encontrarem com seus fundamentos para fazer tudo demasiado "real" tremeluzir. "Algo do fundo vem à tona...", brincava Deleuze (apud Lapoujade, 2015, p. 36).

Falsear o real exige dos corpos fabuladores uma intrínseca relação com o tempo, com o eterno presente. Não seria possível fabular vivendo nas profundezas do tempo ou em busca de verdades imutáveis. Todo o princípio fundante é questionado na presença do falso. Fabular, dizia Deleuze (2013), é exercer a potência do falso, expandindo os tempos do agora.

Fabular implica expandir os possíveis, fazendo ruir certos sentidos e limites. E isso só é possível quando conseguimos produzir cortes nos fluxos como os conhecemos. Cortes de ideias, de afetos, de direções, de virtualidades.

Criar vazios é, talvez, essa arte de indagar pelas potências do falso, da força que ri debochadamente de tudo demasiado real, de tudo inerente à vida. É mesmo assim? Não há outro modo? Nada mais é possível? Ora pois! Neste momento - e apenas neste! -, a função fabuladora cede espaço à fabulação.

Uma vez que nos encontramos com a fabulação, criamos rotas ao vazio, indagamos os falsários da vida, evocamos os limites da visibilidade e enunciabilidade, para que a vida seja potencializada. Aqui fabular é já resistir.

\section{produzir o comum a partir dos currículos}

Mas como fazer o convite à fabulação?

Entramos na escola e, tão logo dizemos de nosso desejo de criar fábulas, somos desacreditados de toda a seriedade. "Tá parecendo trabalho de português agora", disseram uns. Outros foram mais radicais e fizeram da oportunidade uma verdadeira algazarra. "Coé, professor, tá chamando a gente de criancinha?".

Diante da obrigação de uma funcionalidade permanente que a máquina capitalística exige de nós, a pergunta é, decerto, amparada por todas as causas sociais. Quem, afinal, ousa entrar em uma escola e não ter por objetivo assegurar uma funcionalidade? Quando a funcionalidade não é explícita, a escola parece perder, em si, seu caráter único de ensinar. 
Acostumados à lógica de que tudo funciona integralmente e deve obedecer a objetivos claros (Roseiro; Silva, 2018), pôr em jogo a própria possibilidade de criação coletiva e de ampliação do apego à escola parece aos corpos uma ideia demasiado desconexa com a própria função.

Afinal, se a escola existe para ensinar, por quais motivos as pessoas envolvidas deveriam debruçar-se sobre um trabalho de fabulação?

- Aí, 'fessor, 'cê manja de matemática, né? Ajuda a gente aí... a gente tem uma prova 'qui a pouco...

- Pô, boa moleque! Vai lá, professor! Vamo' deixar esse faz de conta aí pra depois, ajuda a gente primeiro, vai? 'Cê é craque na porcentagem, né? Ajuda aí, por favor!

Decerto há, aí, todo um conceito de currículo como metas, competências e habilidades; todo um modo de conceber o mundo como um organismo que deveria funcionar infinitamente. A fabulação - e aqui falamos já da possibilidade de lê-la como apego à vida - é descartável quando o mais imediato assombra a vida. A prova bate à porta e todo o trabalho de pensar os possíveis para o tempo se esvai.

Não há dúvidas: nesse cenário, entenderíamos os currículos apenas por aquilo que pode ser mensurado e avaliado - em larga escala -, deixando de lado as nuances ou, no máximo, compreendendo-as enquanto um regionalismo ou uma necessidade das comunidades locais.

Dadas as políticas curriculares que insistem em quantificar e barbarizar o mundo, transformando toda ação escolar em uma série de competições e classificações, fabular realmente parece não haver nenhuma funcionalidade à vida escolar.

Os currículos, todos sabem, dizem de um plano de nação! Prometem futuros!

Não ao acaso, Tomaz Tadeu da Silva (2013) discute as mutações e os enfrentamentos das teorias de currículo mediante as implicações curriculares para com a vida como um todo. Desde os primeiros estudos de currículo altamente funcionalistas e técnicos, vemos em jogo a própria produção do corpo, das subjetividades que compõem o plano de existência. Todo escrito curricular enseja um modo de produção de vida. Afinal, conforme sugere David Lapoujade (2015), toda organização explicita uma pretensão e uma reivindicação. 
Ao seguir os rastros de Michel Foucault, Tomaz Tadeu da Silva (2013, p. 120) encontra no sujeito os resultados "dos dispositivos que o constroem como tal". Isto é, em dada medida, somos o que fazem de nós. Somos efeito dos jogos de poder no qual estamos inseridos. Na mesma direção, Noguera-Ramírez (2011, p. 219) recorda que "aquilo que identifica a perspectiva curricular não é a prescrição dos conteúdos do ensino, mas a organização do ensino como um conjunto de atividades ou experiências [...] que se espera que as crianças desenvolvam na sua vida adulta".

Seríamos nada mais que peças de xadrez em um tabuleiro demasiado complexo, efeitos de práticas de governamento.

Somos apenas isso?

Decerto, o não ressoa bravamente. Ainda que esteja "afinada com a racionalidade política moderna", criando "subjetividades que se pensam únicas e indivisíveis" ao mesmo tempo que "cria posições de sujeito subordinadas a um todo social" (Veiga-Neto; Saraiva, 2011, p. 9), muitas experimentações de afetos, corpos, tempos e resistências são possíveis também na escola. Discutir os currículos apenas como práticas de governamento ou de sujeição das subjetividades e dos corpos é inviabilizar as resistências infinitas que se espalham pelos corredores, salas de aula, pátios, bibliotecas, banheiros, refeitórios e afins.

Falamos de uma aposta nas filosofias deleuzo-guattarianas ${ }^{4}$ justamente por isto: as discussões no campo dos estudos curriculares podem, sim, ressaltar um caráter largamente controlador. Todavia, é-nos, ainda e sempre, possível expandir nossas forças afetivas para com as escolas e, por conseguinte, para com os currículos e nossos modos de concebê-lo.

Conforme sugere Elizabeth Macedo (2019), nada mais surreal que acreditar em tal plano de nação como algo emergente das políticas curriculares. Nada mais

\footnotetext{
${ }^{4}$ É importante destacar que os estudos foucaultianos não apenas apontam a subjetividade como produção inevitável das relações de poder. Os corpos são, sim, produto dos efeitos de poder. Todavia, há também a possibilidade de resistência nos escritos de Michel Foucault. Com base no conceito de biopotência, por exemplo, Foucault aponta que as resistências são ainda mais fortes justamente onde nos querem mais pacíficos e dominados. Para além desse conceito, é uma boa lufada de ar ler as entrevistas que Foucault deu ao longo de sua vida. Em quase todos os momentos em que o filósofo se punha a conversar com outros sobre seu trabalho, ele destacava o caráter criador das subjetividades. As entrevistas estão quase todas reunidas na coleção "Ditos e Escritos", organizada, no Brasil, por Manoel Barros da Motta.
} 
cruel que insistir em justificativas baratas para a mercantilização da educação do que a tal crença de que os documentos curriculares criam a nação que almejamos. Atrelando financiamento às avaliações, os tais "planos de nação" - vulgarmente chamados de documentos curriculares - não fizeram outra coisa senão assegurar a mercantilização da educação desde sua intensificação das propostas neoliberais nos anos de 1990.

Recusamos essa proposta de imediato.

As promessas de futuro levantadas por certas noções de escola são especulativas. E, conforme Culp (2020) lembra, a especulação é a modalidade de promessa de futuro ancorada na perpetuação infinita da máquina capitalística.

Não para menos, vemos a função da escola atrelar-se às promessas de futuro mercantis. Os alunos, quando indagados sobre o papel da escola, veem na instituição uma chave de acesso ao mundo dos adultos, e, mais que isso, ao mundo do mercado de trabalho. Conforme Costa (2017) e Dias (2018) evidenciam em suas teses, os futuros das alunas e dos alunos parecem depender da escola; mais ainda, de ir bem na escola para que outros futuros possam ser acessados.

O problema é que, na lógica composta nesses relatos, os outros futuros são ainda completamente mercantilizados, futuros que ressaltam a qualidade de vida, mas da vida individualizada, da vida vista sob uma perspectiva salvacionista. Futuros passíveis de ser especulados.

- Por nada não, professor, mas tem hora que todo mundo se pergunta pra que a gente vem pra cá, sabe? Nem tô falando desse momento aqui com você não. Pra escola, saca? Pra quê? Tenho futuro aqui não, 'fessor. Foi mal. Tô fora desse negócio aí da história da escola.

Infelizmente, o real imediato parece falar mais alto. Quando vemos o movimento de pesquisa ser encaminhado para uma aula extra de matemática para atender às expectativas curriculares de uma turma ou quando a escola parece não se preocupar com as produções de sentidos, parece-nos que as lutas por possíveis são deixadas de lado.

Contudo, não podemos fazer essa única leitura. 
Pensar os currículos escolares requer, nos dizeres de Janete Magalhães Carvalho (2009), pensar a própria escola como um espaço de produção ativa de suas relações. A escola relaciona-se com a sociedade, evidentemente, mas, na instituição, ela opera explorando a vida por meio de conversas, de práticas curriculares que colocam o próprio mundo à disposição daqueles que se envolvem na prática escolar. É o mundo - a sociedade, suas máquinas, seus arranjos, seus saberes - que é posto em prática dentro das escolas mediante redes de conversações curriculares que dão a conhecê-lo com base em nossas expansões afetivas.

Ainda que as escolas tendam a nomear por currículo uma série de documentos basilares que regulam ou "norteiam" as práticas de ensino, os currículos efetivamente se apresentam como práticas que visem colocar o mundo em exploração.

Não longe dessa discussão, por sua vez, Fernando José de Almeida e Maria da Graça da Silva (2018) apontam o currículo como espaço onde se exerce o afeto. “O afeto de quem é tocado pelas questões da humanidade e não apenas pelo consumo de espetáculos e redes tecnológicas, ditas sociais. O afeto curricular é o afetar-se pelo mundo" (Almeida; Silva, 2018, p. 608).

Os currículos, em suma, são responsáveis pela produção do mundo que desejamos, tecendo entre os corpos envolvidos nas práticas escolares o comum, que permite tal produção.

A questão, entretanto, é que, para criar, é preciso que haja afetos entre os corpos e que cada pessoa consiga enxergar-se na relação infinita e imediata com os outros. Para criar, é preciso sair do indivíduo (Rolnik, 2018). Não há criação onde não há afetos, não há criação onde não se estabelecem relações entre os corpos.

Colocamo-nos a produzir quando os corpos se veem uns aos outros como vidas capazes de se encontrarem, de se afetarem e produzir, a partir desses afetos, desejos de mundo. E o comum, conforme sugere Janete Magalhães Carvalho (2015), é da ordem dos encontros entre os corpos. O comum seria justamente o lugar onde se encontram os corpos, as ideias, os afetos e esses se colocam em uma produção coletiva da própria vida. 
Daí a argumentação de falar de currículos como expansão de uma zona de comunalidade (Carvalho, 2009). Currículos organizam-se em redes de conversações nos interiores das escolas para produzir afetos capazes de expandir o comum entre os corpos.

O problema é que, conforme sugerem Michael Hardt e Antonio Negri (2016), a máquina capitalística se ocupa justamente em extrair de nós toda a força coletiva. Na lógica do capital, tudo o que geramos, tudo o que produzimos está em via de ser codificado e imediatamente transformado em mercadorias: nossos sonhos, nossas ideias, nossas paixões. Sempre que os corpos se colocam em produção de algo, o produto dessa relação tenderá ao controle e à financeirização. Afinal, “a sociedade capitalista parece empenhada em eliminar ou mascarar o comum privatizando os meios de produção e, na verdade, todos os aspectos da vida social" (Hardt; Negri, 2016, p. 176).

Eis a justeza de retirar das práticas escolares toda a lógica do indivíduo autossuficiente e de aumentar, em cada corpo, as zonas de sensibilidade da vida. No contexto da pesquisa, perguntávamos como conversar com as alunas e os alunos sem que, de antemão, tivéssemos de assumir um papel demasiado burocrático. Como produzir zonas de comunalidade entre os corpos que são, a todo o momento, capturados pelos agenciamentos capitalísticos, privatizados em sua máxima da individualidade? Em meio a uma turma de moleques e marmanjos, como pôr a própria criação em indagação?

- 'FESSOR! ISSO É CHICLETE? - grita uma menina passando pelo corredor na hora da entrada.

- Sim, eu comprei para uma rodada de brincadeiras que vou fazer com minha turma amanhã...

- Professor, de coração! Se você incentivar a gente com isso, é bem capaz da conversa render mais, sabe? 'Cê vai na nossa sala hoje, né? Podia descolar uns chicletes pra quem participa sempre da conversa... eu tô sempre do seu lado, você sabe, né? Até fiz um desenho da menina lá que a nossa turma criou, te mostrei? Depois passa lá pra ver! Mas, ó!, leva chiclete, tá? Vou falar pra geral participar hoje que vai rolar chiclete na história!

A resposta, por vezes, pode ser isto: um doce, uma música ou um jogo de baralho. Não prêmios de participação, mas modos de aproximação, de deixá-los 
mais à vontade. Um desafio às avessas. Uma lista infinita de coisas poderia aparecer aqui, entretanto, abstratamente, podemos dizer apenas que a criação entra em jogo quando há, entre os corpos, possibilidades de criar conversas.

A isso, justamente, Carvalho (2009) - à guisa de uma leitura spinozana chamou de zona de comunalidade.

Ora, é preciso, de imediato, lembrar que uma sala de aula é já e sempre uma zona de comunalidade. Em termos arquitetônicos, tínhamos a condição sine qua non para a produção do comum: o encontro entre corpos ${ }^{5}$. Afinal, como Hardt e Negri (2016) sugerem, o comum se estabelece sempre que os corpos se dão ao encontro. Todavia, o encontro não podia ser apenas da ordem física, mas também de modo afetivo e, portanto, cognitivo. Por isso, a bala, a bisca, o riso. Uma sala de aula e uma escola nunca são espaços de corpos isolados, de pessoas autossuficientes. Dentro desses espaços, ocorrem trocas afetivas, conversas, partilhas de ideias, de modos de enxergar e cuidar da vida que inevitavelmente acabam por produzir um comum entre eles (Carvalho, 2009). Como, então, ampliar as conversas?

- Eita, pessoal. Que cara é essa?

- A prova de matemática acabou com a galera, 'fessor.

- A maior nota foi 4 , 'cê acredita?

- Eita!

- A professora tinha falado que ia cair porcentagem, aí caiu um troço lá na prova que ninguém nem sabe o que é...

- É binômio, bocó.

- Essa merda aí mesmo.

- Ué, e vocês vão deixar assim baixo? Se ela falou que ia cair uma matéria e caiu outra, dá para fazer uma reclamação com as pedagogas. Quem é o líder de turma?

- A gente tem isso não.

- Passou da hora de ter, né? O ano já tá até acabando... bora lá, vou ensinar a vocês como fazer essa reclamação...

- Mas e a nossa história, 'fessor?

- Pô, 'bora colocar essa merreca na história!

- Isso! A turma do $7^{\circ}$ B não tinha criado uma professora filha da mãe para a história. - Vamos colocar ela devolvendo as provas na história!

\footnotetext{
${ }^{5}$ É importante destacar que, para muitos de nós, esse encontro parece hoje já estar na berlinda. Em 2020, enfrentamos um contexto de ensino remoto disparado pela pandemia da Covid-19 e, hoje, o modo de operacionalização de uma aula parece variar ainda mais, podendo ser compreendida como uma territorialização de espaços cibernéticos, como um esvaziamento de afetos em uma sala de aula presencial ou mesmo como uma ficção de aula que ocorre por entregas de papéis quando a figura docente é quase radicalmente engolida pela burocracia.
} 
- Isso! E um zé mané vai tirar uma com a cara dela!

- Você já tá se achando esse zé mané, né, garoto? Aiai, vai vendo!

O comum surge daí, desse encontro entre currículos e insurreições, entre vida e seu grau máximo de apego a ela, de ampliação de nossas forças e de nossas lutas.

Se nos é preciso, para a criação, que zonas de comunalidade sejam criadas, também devemos nos abrir aos afetos de uma sala de aula. Se, dentro de um espaço de $5 \mathrm{~m} \times 5 \mathrm{~m}$ cabem 30, 40, 50 corpos, é-nos imperativo que cruzemos com esses todos para convidá-los à criação.

Uma vez que não pensamos nos currículos como manual de competências, e sim como prática de cuidado com o mundo, propomos aos próprios alunos imaginar quais forças seriam necessárias para que as escolas se tornassem espaços mais abertos e acolhedores a eles. Ou, ainda melhor, que as escolas fossem capazes de indagar os futuros possíveis para as gerações que vêm.

Nas salas de aula, geralmente em espaços demasiado pequenos, ocupam 30 , 40, 50 corpos. Tínhamos, em cada sala, 30 alunos ocupando um espaço de $5 \mathrm{~m} \times 5 \mathrm{~m}$. 30 alunos em trocas constantes de piadas, de implicâncias, de amores, de escapadas, de desafetos e de desejos.

Quando a própria escola é posta em questão, enfim, vemos começar a surgir entre as algazarras certas conversas. O convite à criação, logo descobrimos coletivamente, não obedece às regras das perguntas-e-respostas.

\section{fabulate ergo sum}

Numa época em que a arte se reduz à criatividade (Rolnik, 2018) e o funcionalismo responde à produtividade capitalista (Roseiro; Silva, 2018; Han, 2017), fazer pesquisa, para nós, não é apenas registrar infinitamente algo ou mesmo pretender dar conta de tudo. A pesquisa e principalmente a pesquisa em educação devem suscitar insurreições, intensificação do apego à vida, mobilização coletiva para enfrentar as mazelas criadas pela maquinaria Capital.

Tínhamos uma única pretensão: instaurar, com os alunos, possibilidades insurrecionais de escola. Aos modos de Alvim, Mação e Roseiro (2020), reconhecemos que toda escola abriga uma infinidade de lutas estudantis e as escolas 
não conseguem sobreviver sem lidar com essas lutas. Há resistências e revoltas por todos os cantos em uma escola, e, se uma pesquisa em educação não dá conta delas, podemos apenas rir de sua pretensão de produção de verdade que, entretanto, está já alheia à própria materialidade da escola.

Fabulávamos, portanto, no real para ensejar mais desejo de vida.

Afinal, a fabulação produz algo muito maior que a própria vida, ainda que apenas na vida ela seja possível. Os personagens e corpos fabulados são demasiado vivos e vívidos para serem vividos (Deleuze; Guattari, 2010), mas, por isso mesmo, suscitam a vida e o apego a ela.

Porque, diante de uma força fabulatória que realmente amplie o presente, não conseguimos escapar sem sermos atingidos por blocos de sensação.

Vimos nascer desses encontros fábulas de escola que, a todo o momento, afirmaram lutas e brechas tão ordinárias nas escolas ${ }^{6}$. Apesar de muitas dificuldades - durante a pesquisa, não apenas tivemos um grande número de alunos que não se envolveu ativamente na fabulação, como chegamos ainda a ter briga dentro da sala -, as fábulas criadas efetivamente falavam de escola e simultaneamente de uma escola que não existia.

Isso ocorre porque a fabulação, apesar de ser iminentemente real, tem de carregar algo de fictício, de demasiado vivo, de improvável. Não nos interessa fazer emergir apenas aquilo que já existe. É preciso evocar imagens de mundos incompossíveis para ampliar os compossíveis.

Jean-Christophe Goddard (2017) rouba o Descartes de Leminski para confrontar um Espinosa radicalmente transmutado em um brazuca, negão e sebento para, no limite, descobri-lo ainda mulher. Eduardo Viveiros de Castro (2015) faz do corpo xamânico um hospedeiro para outros corpos. Em ambos os casos, o corpo não faz outra coisa senão fabular; narra o que sempre soubemos: o controle tem medo do fantástico, do inexplicável. Conforme destaca Goddard (2017, p. 20), "seres fantásticos continuam assombrando os brancos. E eles, coitados, não sabem o que

\footnotetext{
${ }^{6}$ Todas as fábulas produzidas com os alunos podem ser encontradas em "Feiuras: insurreições do corpo na escola" (Roseiro, 2019).
} 
pensar destes desconhecidos, a que concedem de boa a hospitalidade de seu próprio universo de pensamento, mas dos quais não sabem aprender bulhufas".

Convidamo-lo(a) para ler o branco do Goddard como todo modo dominante de produção. O branco é, ali, inclusive a ciência.

Para convidar à fabulação é, então, necessário desemaranhar-se das branquitudes. Roubamos, então, um conceito de branco para encardi-lo, para dar a ele nuances ameríndias, negras, femininas, transexuais. Quando tiramos a fabulação da produção de verdade e a lemos como modo de ampliar as possibilidades de vida, é-nos imperativo, então, que a fabulação não seja conduzida pelos corpos dominantes.

Antes ela fosse evocada por ratos, por crianças, por bactérias ou por vazios.

Onde, então, fabularíamos?

Ora pois! Só se fabula no real! Só se fabula onde a vida encontra forças maiores que ela. Fabulamos quando deparamos com algo intragável, com aquilo que nos arranha a garganta. Como conceito, a função fabuladora é deleuziana, todavia, como método, ela alimenta-se da capacidade de um corpo em rir e em debochar de nossas possibilidades de evocarmos nos outros um surto ou o pânico da incerteza. Quando a fabulação efetivamente começa a ganhar corpo, começa a fazer parte da vida coletiva, ela é, inclusive, passível de ser apresentada a terceiros para pôr em dúvida o próprio presente.

Rejeitar o branco e as branquitudes implica assumir as forças fantasiosas para nos relacionarmos com o real.

Se a noção de resistência deleuziana é a de uma força que antecede às capturas organizadoras e/ou capitalísticas (Deleuze; Guattari, 2011; Alvim, 2011), o conceito de insurreição diz de ações que afirmam a resistência em movimentos (Comitê Invisível, 2016). Não que as insurreições sejam revoluções, mas, no mínimo, elas tomam corpo deliberadamente para enfrentar as forças capitalísticas.

Fabulação e insurreição são, portanto, movimentos de ampliação das próprias possibilidades de vida. Por isso, dizíamos do apego à vida, daquilo que nos faz ter mais vontade de vida e de enfrentamento às forças anestésicas. Afinal, entre fabulação e insurreição, um dos conceitos emerge da possibilidade de criar o 
mundo; outro agride o mundo. Na fabulação, a violência encontra o corpo de um personagem em um mundo impossível de respirar; na insurreição, o corpo abandona qualquer individualidade para respirar o impessoal; a fabulação agride o mundo com sua possibilidade, com sua estética da ficção iminentemente real; a insurreição pede passagem para outros lugares, desvendo a criminalidade de quem sorri; a fabulação agride o presente; a insurreição desfaz o amargo de um corpo no abraço; na insurreição, o corpo dramatiza a ironia do corpo egocapitalizado, enquanto fabula transgredir a solenidade da vida. Ou seria o contrário?

Seja como for, falamos de um corpo fabulado para fazê-lo vivo. Mas que fique registrado: você nunca é dono da personagem que cria. Outros tantos a criarão com você, outros lhe dirão o que fazer. Aceite: outros corpos fabulam esse mesmo corpopersonagem enquanto você trabalha nele. De nada vale manter a fabulação em segredo ou mantê-la como mentira! Conte-lhes das fábulas e do exercício, convideos a participar. Como em um grupo de corpos sussurrantes no deserto estéril, a vida pede para ser contada: "Você acabou de vir do mundo! Conte para nós, conte! Fale sobre o mundo"7. Numa roda, onde os outros são corpos - e, em nosso caso, eram crianças e adolescentes hábeis em nos insultar -, por que não dar a fabular? Por que não fazer com que as próprias histórias fossem fabuladas? Falar para além do "eu", seja lá quem pronuncia, quem fala, quem escreve, quem rabisca. "É possível fabular no real?". Ora, fabulamos apenas no real. Longe da imanência, a fabulação é outra coisa qualquer, não um método.

A imanência faz-se evidentemente fabuladora. E, para fabular, é-nos preciso colocarmo-nos a ouvir as forças inaudíveis, a transformar os muxoxos e os silêncios em personagens que tecem conversas inteiras entre resmungos, que fogem nas asas de um assovio.

Talvez a fabulação metodológica seja a possibilidade de criar um corpo existente apenas nas virtualidades da vida. A função fabuladora é sempre dos pobres - e, por conseguinte, sempre um insulto -, dos corpos esdrúxulos, bizarros, da carne comum; a fabulação faz as infâmias agruparem-se, criarem um corpo (ou corpos!) coletivo, corpo desejante ("Sempre mais desejante que desejado!"); a

\footnotetext{
${ }^{7}$ Cena levemente alterada referente ao livro A luneta âmbar, escrito por Philip Pullman.
} 
fabulação, porque fabulosa, cria do falso a monstruosidade. Joga contra a lógica cartesiana. Do cogito ergo sum nasce o fabulate ergo sum. A mudança não é apenas de um termo, mas das condições de emergência. Não mais é um corpo pensante que existe por si só, mas um corpo que existe a partir dos outros que se põem em criação com ele. A questão é de corpos que se juntam, se unem, traçam comuns. Aqui a tradução não é "Fabulo, logo existo", mas "Fabulais, logo existo".

A fabulação é obra coletiva.

\section{pequeno apanhado fabulador}

dica\#1. Crie - nunca para si! cria-se para o mundo! - um personagem que destitua o "eu" de sua boca e agrupe existências infinitas.

dica\#2. Dê-lhe um nome próprio que seja "a apreensão instantânea de uma multiplicidade" (Deleuze; Guattari, 2011, p. 66) e, em absoluto, "que jamais teu nome próprio vire uma máscara para um índio, uma fantasia de Carnaval" (Goddard, 2017, p. 57).

dica\#3. Faça-o berrar, bater no vidro, escancarar os escândalos tanto quanto os segredos. Não o deixe se calar, salvo momentos que lhe exijam a fala.

dica\#4. Que o falso jamais seja um limite e que o imediato jamais fale demasiadamente alto.

Pequeno lembrete. É óbvio que, no trato com o falso deleuziano e com a ficção foucaultiana, com o virtual e com o enfrentamento ao presente, acabamos também por correr um duplo risco que, nos dizeres de Gabriel da Cunha (2014, p. 97), pode nos arremeter à "ambiguidade entre a pobreza do desfecho moralizante e o percurso fantástico de pura criação".

Esse lembrete poderia ser inserido em qualquer método.

dica\#5. A fabulação só existe no real. Donde mais ela se aventurar, chamarse-á outra coisa.

dica\#0. Fabulais, logo existo.

\section{referências}

Almeida, Fernando José; Silva, Maria da Graça Moreira da. Currículo e conhecimento escolar como mediadores epistemológicos do projeto de nação e de cidadania. e-Curriculum, São Paulo, v. 16, n. 3, p. 594-620, jul./set., 2018. 
Alvim, Davis Moreira. Foucault e Deleuze: deserções, micropolíticas, resistências. (Tese de Doutorado). São Paulo; PUC-SP, 2011.

Alvim, Davis Moreira; Mação, Izabel Rizzi; Roseiro, Steferson Zanoni. Ano 2091 silêncio nas filosofias da educação: por uma cartografia das resistências escolares. Educ. Pesqui., São Paulo, v. 46, e223171, 2020.

Bergson, Henri. As duas fontes da moral e da religião. Tradução de Miguel Serras Pereira. Lisboa: Almedina, 2005.

Butler, Judith. Quadros de guerra: quando a vida é passível de luto? Tradução de Sérgio Tadeu de Niemeyer Lamarão e Arnaldo Marques da Cunha. Rio de Janeiro: Civilização Brasileira, 2015.

Carvalho, Janete Magalhaes. O comunismo do desejo no currículo. In: Ferraço, Carlos Eduardo; Rangel, Iguatemi; Carvalho, Janete Magalhães; Nunes, Kezia Rodrigues. (Orgs.). Diferentes perspectivas de currículo na atualidade. Petrópolis: DP et Alii; Nupec/Ufes, 2015.

Carvalho, Janete Magalhães. O cotidiano escolar como comunidade de afetos. Rio de Janeiro: DP et Alii, 2009.

Comitê Invisível. Aos nossos amigos: crise e insurreição. Tradução de Edições Baratas. São Paulo: n-1 edições, 2016.

Comitê Invisível. Motim e destituição agora. Tradução de Vinicius Honesko. São Paulo: n-1 edições, 2017.

Costa, Crisolita Gonçalves dos Santos. O sentido da escola para os jovens do Ensino Médio: um estudo na escola Enedina Sampaio Melo. Tese (Doutorado em Educação) - Instituto de Ciências da Educação, Universidade Federal do Pará. Belém, p. 226, 2017.

Culp, Andrew. Dark Deleuze: pela morte deste mundo. Tradução de Camila de Moura. São Paulo: GLAC Edições, 2020.

Cunha, Gabriel Torelly Fraga Correa da. Memória e fabulação em Henri Bergson: considerações sobre a experiência do tempo no ensino de história. (Dissertação de Mestrado). Porto Alegre: UFRGS, 2014.

Deleuze, Gilles. Francis Bacon: a lógica da sensação. Tradução de Roberto Machado. Rio de Janeiro: Zahar, 2007.

Deleuze, Gilles. A imagem-tempo. Tradução de Eloisa de Araújo Ribeiro. São Paulo: Brasiliense, 2013.

Deleuze, Gilles; Guattari, Félix. O anti-Édipo: capitalismo e esquizofrenia 1. Tradução de Luiz B. L. Orlandi. 2. ed. São Paulo: Ed. 34, 2011.

Deleuze, Gilles; Guattari, Félix. O que é filosofia? Tradução de Bento Prado Jr. e Alberto Alonso Muñoz. 3. ed. São Paulo: Ed. 34, 2010.

Dias, Danilo Borges. Educação, migrações e sociabilidades juvenis bolivianas em São Paulo $e$ Buenos Aires. Tese (Doutorado em Educação) - Escola de Educação, Tecnologia e Comunicação, Universidade Católica de Brasília. Brasília, p. 231, 2018.

Foucault, Michel. Prefácio. In: Foucault, Michel. Ditos e Escritos, volume IX: genealogia da ética, subjetividade e sexualidade. Tradução de Abner Chiquieri. Rio de Janeiro: Forense Universitária, 2014.

Goddard, Jean-Christophe. Brazuca negão e sebento. Tradução de Takashi Wakamatsu. São Paulo: n-1 edições, 2017. 
Han, Byung-Chul. Sociedade do cansaço. Tradução de Enio Paulo Giachini. 2. ed. ampliada. Petrópolis: Vozes, 2017.

Hardt, Michael; Negri, Antônio. Bem-estar comum. Tradução de Clóvis Marques. Rio de Janeiro: Record, 2016.

Lapoujade, David. Deleuze, os movimentos aberrantes. Tradução de Laymert Garcia dos Santos. São Paulo: n-1 edições, 2015.

Macedo, Elizabeth. A educação e a urgência de "desbarbarizar" o mundo. eCurriculum, São Paulo, v. 17, n. 2, p. 1101-1122, jul./set., 2019.

Marques, Edgar. Possibilidade, compossibilidade e incompossibilidade em Leibniz. Kriterion: Revista de Filosofia, Belo Horizonte, v. 45, n. 109, jan./jun., p.175187. 2004.

Noguera-Ramírez, Carlos Ernesto. Pedagogia e governamentalidade ou Da Modernidade como uma sociedade educativa. Belo Horizonte: Autêntica Editora, 2011.

Pelbart, Peter Pál. Ensaios do assombro. São Paulo: n-1 editora, 2019.

Silva, Tomaz Tadeu da. Documentos de identidade: uma introdução às teorias do currículo. 3. ed. 4. reimp. Belo Horizonte: Autêntica Editora, 2013.

Rolnik, Suely. Esferas da insurreição: por uma vida não cafetinada. São Paulo: n-1 edições, 2018.

Roseiro, Steferson Zanoni. Feiuras: insurreições do corpo na escola. Dissertação (Mestrado em Educação) - Centro de Educação, Universidade Federal do Espírito Santo, Vitória, 2019.

Roseiro, Steferson Zanoni; Silva, Sandra Kretli da. Currículo disfuncionais: inventar as lutas contra o capitalismo. Educ. Real., Porto Alegre, v. 43, n. 3, p. 11151130, jul./set., 2018.

Safatle, Vladmir. O que é fascismo? Cult, São Paulo, n. 271, out. 2018. Disponível em: https://revistacult.uol.com.br/home/o-que-e-fascismo/. Acesso em: 11 abr. 2021.

Santos, Boaventura de Sousa. Renovar a teoria crítica e inventar a emancipação social. São Paulo: Boitempo, 2007.

Veiga-Neto, Alfredo; Saraiva, Karla. Educar como arte de governar. Currículos sem Fronteiras, v. 11, n. 1, p. 5-13, jan./jun., 2011.

Viveiros de Castro, Eduardo. Metafísica canibais: elementos para uma antropologia pós-estrutural. São Paulo: Cosac Naify; n-1 edições, 2015.

recebido em: 01.01.2021

aprovado em: 02.05.2021 